Journal of Education and Vocational Research

Vol. 3, No. 10, pp. 313-318, Oct 2012 (ISSN 2221-2590)

\title{
Education and Learning in the 21st Century: An Emergency Agenda for Sustainable Development
}

\author{
Ivan Siqueira \\ University of Sao Paulo, Sao Paulo, Brazil
}

\begin{abstract}
The $21^{\text {st }}$ Century has observed an increase transformation based on economy and social patterns. The challenging of education is now prepared for the future, not for the present. The changing environment of learning is related to competencies and skills rather than in particular subjects and theories. How to teach what is not present yet? Why education must be profoundly related to both Information and Communication Technology and human ethnic? This paper is dedicated to highlight some of these points, bringing some reflections regarding these topics about the relationship between Africa and Latin America, especially Brazil.
\end{abstract}

Keywords: Education, Sustainable Development. Information and Communication Technology, Africa and Brazil

\section{Introduction}

Ladies and Gentlemen, in 1992, the Rio de Janeiro city (Brazil) received the United Nations Conference on the Environment and Development, also known as "EC092" or "Earth Summit". About 100 heads of state and more than 15.000 activists from several places in the World went to Rio to discuss about Biodiversity, Climate Change and Forests survive. After long debates, became known the Agenda 21, a report with 2.500 recommendations to promote the so-called sustainable development. The focus were in climate change, forestry biodiversity, bio fuels, research for sustainability, reducing carbon emissions, economy, population and development indicators. Ten years later, the World Summit on Sustainable Development (Rio+10) was held in Johannesburg (South Africa). It was clear that there were so much to do, on the other hand, a little list of effective actions was done to accomplish any form of sustainability. In mid-June this year, again in Rio de Janeiro (Rio+20), the World Summit discussed the problems of a equitable use of natural researches, promotion of good food, health, habitation, sociability among different people across the globe, respect for ethnic differences, in short - a good life for all mankind. Nevertheless, the economists said that this "earth paradise" is doubtless associated with the conditions of world economic growth, particularly after the Leman Brothers' crash in 2008 and the following global financial crisis (2008-2012), (The World Bank, 2012). The enlargement of crisis in Euro zone practically discourages any optimism associated with efficient sustainable actions that were discussed in Rio+20. In today's Europe, the unemployment rates are about $5 \%$ for Germany, 10 for France but 24 for Spain, and the project 2012 economic growth rates of $0.6 \%$ for Germany, 0.5 for France but a dramatic rate of $-3.3 \%$ (minus 3.3) and -1.8 (minus 1.8) for Portugal and Spain, respectively (The New York Times, 2012). The first of these thematic conferences promoted by United Nations was held at Stockholm, Sweden, in 1972. All of conferences have shown the emergence of an International Agenda about these topics. Unfortunately, in none of then we have seen education ranking the central point of the subject. Is it possible a sustainable development, a responsible use of natural researches, respect for ethnic differences or other patterns of consumption without a new model of education? Even the deliberations about human's rights state by The Committee on Economic Social and Cultural Rights, that everyone should have access to safe and potable water, adequate sanitation, supply of safe food and healthy occupation, is it possible and sustainable without a new education? (United Nations High Commissioner for Human Rights, 2012).

By new school, I understand a model of education where students learn that respecting nature leads to respecting people, no matter if they are close or far way. I think we must become aware of the connections between our lifestyles and the education we have had. In addition, what about the impact of Information and Communication Technology (ICT) on all levels of education: early childhood, primary, secondary and tertiary? If what we really desire is walk towards a new world, then we need to revolutionize the shape of our education. The school should provide exciting experiences and valuable understanding of how the world 
works. How to do it without understanding that computers are profoundly changing the way we communicate, engage in politics, and learn? However, a new education program that includes the ICT objects requires investments and public policy. In this subject, Brazil and most of Latin America and Caribbean have lived roughly the same difficulties as nation like Nigeria, South Africa and other developing countries: lack of qualified ICT staff, cost of equipment and mainly non-inclusion of ICT programs in all levels of teachers' training (Kwache, 2007; Brunner, 2004; Lopez Segrera, 2007). Many studies claim that the model of economic progress that brought comfort and welfare state in developed countries of Europe and North America, which have been exported to developing countries like Brazil, Russian, India, China and South Africa (BRICS), is not possible for the entire population of the planet (Meadows et al., 1972 and 1992; United Nations, 1997; Aspalter, 2003). If the conferences of United Nations of the last 40 years have not achieved their goals yet, at least they highlighted that world economic and its social basis are not sustainable; especially if we considered that we going to live in a planet where the population is expected to be about 10 billion by the year 2050 (United Nations, 2010). More and more, we see that social conditions that favor wasteful behaviours, an economic dependence on non-renewable fossil fuels, and an exploitative of renewable resources so much faster than environment regenerates cannot go on forever. Here, the point is not if the concept of sustainability is or is not innocuous enough. The main idea is that development and social welfare are deeply related to education possibilities. The central argument of this lecture is that the general conditions of sociability in this planet, which produce at the same time chronic hunger and obesity epidemic, waste and need, and the consequence discarding of products that pollute rivers, oceans and atmosphere, are not an utterly problem of economy, but fundamentally a matter of education.

In fact, "None of us today, whether we're managing a house or running a business, is living in a sustainable way" (Magretta, 1997). Therefore, we need to modify our view about life and who we are, something like to be aware that happiness is not reach by an immeasurable increase of consumption. More and more, there are evidences to support that education has a essential position in our present world, not only because one of the strongest purposes of education is to provide new knowledge and innovation to solve problems; but because education, from now on, has a primary role in an increasingly urban planet, where the conditions of life will be progressively more related with the powers of education. However, we are in a dramatic situation - most of education systems the world has seen are not comparable to the crucial troubles we observe. I would like to point out some ideas about the complex role of education, especially for development countries, highlighting analogous aspects that could step up a welfare state with social and spiritual values, economic growth and good cultural relations between the two continents: Africa and South America, especially Brazil. I would like to remember the approach suggested by Lévi (1964), in which he showed the effectiveness of music as a natural framework, whose properties would allow both devise logical thinking and the aesthetic virtues of societies. I assume that there is a profound crisis in the values and social functions of education in the $21^{\text {st }}$ century, mostly because we are not "listening" properly the complex and organic structure in which the education is inserted. We are trying to pick up "notes" of a great musical device when what we need is to develop a capacity of "structural hearing" (Salzer, 1982). Therefore, a thoughtful understanding of the new economic logic and sociological conditions in which education is based may favor knowledge of its nature and possibilities in the present time, mainly for developing countries.

\section{Informative and Cognitive Capitalism}

During the 1980s and 1990s, a related economic situation was seen in several countries in Latin America. It was a set of 10 general principles that US government and International Financial Institutions like International Monetary Fund and World Bank believed were indispensable to poor and developing countries increase their economies rates. This economic vision suggested the importance of macroeconomic stability and integration into the international economy. That neo-liberal view of globalization included, among others: deregulation, i.e., the elimination of regulations that obstructed the entry of new companies or restricted competition; privatization of state enterprises; trade liberalization and increasing of foreign investment; secure and respect for intellectual property right and above all the reduce role of the state (World Health Organization, 2012). This policy was later called of Washington Consensus, a neoliberal platform that invited poor and developing nations to adhere to a new movement of economic progress and wealth improvement. If the countries followed what was prescribed, they would accomplish a virtuous circle of development. Although there were many differences stages in economic patterns in Latin America, the 
consequences of this orthodox laissez-faire produced similar outcomes in many countries: the weakened of government institutions in favor of corporate profits, the subsequent expansion of unemployed workers, and a perverse concentration of wealth. During 1980s, Latin America International Debt increased up until a rate of $45 \%$ of its full export marked. In comparison, after the I World War, Germany paid no more than $8 \%$ of its exports (Sobrinho, 1994). I have not a deep insight about "Structural Adjustment Programmers" (SAPs) in Africa, also promoted by International Financial Agencies but it appears that the results were very close to what I described about Latin America (especially Brazil and Peru): privatization of state companies in order to attract foreign direct investments (FDI), closure of small local enterprises, trade liberalization and incorporation of the great part of national food production by export trade systems. What does all this have to do with education? Well, for me, this movement of liberal capital has culminated in the current situation we are facing. The situation before is really important to understanding why the ideology of liberal capitalism in the 20th century never promoted education idea as a fundamental tool for developing countries; and why the discourse of education became a new worldwide expression. I have not enough time here to carefully explore this subject matter. I just wanted to mention that my opinion is that we are living in another movement of capitalism expansion, and this movement is powerfully associated to what occurred in the 1990's - the internet phenomena and the transformation it has provoked.

Today, it seems clear the links between the worldwide boom of internet in the 2000s and the deteriorating of the previous economic model. Therefore, the paradigm of digital economy has been used to justify the need of a new education model. Well, at this point I shortly would like to focus on the links between this need of a new paradigm for education and the tremendous transformation of world economic base, which has affected the way people live all over the world and especially provoking a lot of noise at the university. I assume that the policies that provided no effective eradication of poverty or a progressively reduce of inequality between the northern and southern populations in 1980 and 1990s also favoured the coming out of the so-called cognitive capitalism. The situation we live now is directly related to circumstances that have been occurring in the last thirty years. We, in African and in Latin America, did not prepare ourselves for the challenges we are and will face throughout the $21^{\text {st }}$ century. Finally, I got to the point of this lecture - the economic growth may or not improve education, but an effective change in education has more chance to bring new outcomes to social lives, including those related to economy issues.

\section{New Schools for New Times}

One of the most influential thinkers of Brazilian education, Paulo Freire (1921-1997) believed that literacy education must be a tool not only for reading words, but also for reading the world (Freire and Macedo, 1987). He made import contributions about the relationship between social class and the process of acquire knowledge in tradition schools. At young age, he lived among poor families and country workers in the northeast of Brazil, so he reached a deep comprehension about the disconnections between the elitist educational system we had and the real lives of the working class. As he later saw, that situation was not restricted to Brazil. Freire's pedagogic view pointed out that education should provide tools and practice for students' development of critical think, which would allow the understanding of the historic, social and economic conditions. The student then would face the problems as subject of his own conviction (Freire, 1973). Freire frequently said that classes should be an exchange dialogue between teacher and students. As we may seem, he was already concerned of what we have been lately calling "autonomy" and "competence". Much of Freire's education thought, like his "banking concept of education" (the teachers teach and the students are taught), is still very common in most forms of current worldwide schooling. Freire's theory of learning was discussed and applied in United States, Europe and Africa, especially Guinea-Bissau (Freire, 1978). Freire's pedagogy was not a priori technique to be imposed, but a political practice that provides the knowledge, skills and social approach. While enable students to expand their own possibilities of being critical citizens, it favors their participation on the destinies of effective democracy. For Freire, critical thinking was a tool for self-determination and social engagement, not a routine of simply reproducing the past and understanding the present. We could say that, in Freire's terms, critical thinking and learn to learn were a way of thinking beyond the present and beyond the immediate confines of one's experiences. In short, education should introduce students into a critical dialogue with themselves, with history, love and passion, with reality and imagination. At his time, Freire's pedagogy provided intellectual support and theoretical tools for poor students struggled against the oppression of lack of information. Now we are living in a world 
that for the first time in human history we are not dealing with the lack of information but with a big amount of it. There is more information that anyone can assimilate. On the other hand, we have to consider that modern school is an example of an extremely problematic institution, which offers highly resistant to essential reforms. Many works show that we have an education unsuited with the principles of knowledge society (Bohme and Stehr, 1986; Aronowitz, 2000). However, what principles are these?

Many detailed studies on this subject were made by French and Italians (Corsani et al. 2001; Rullani, 2004; Fumagalli and Vercellone, 2007; Moulier-Boutang, 2007). Rullani say that the central idea is that the value of knowledge is fragile and tends to turn down. His notion about the value of knowledge comprises the composition of three drivers: the performance and application (maximizing); the number of multiplying effectively; and sharing rate among people. Therefore, the paradox is that there is a capitalist necessity of free reproducibility of knowledge and, at the same time, the non-reproducibility of the material. That is why the knowledge-based economy requires constant innovation. Therefore, to play this game, our students must learn the rules. Therefore, the creation of value upon material is made through the production of knowledge. This explains the necessity of the monopoly of patents, copyright and all intellectual property rights. In order to compete in this knowledge-based market, our students must learn the mechanism of the reproduction of the cognitive and relational abilities, i.e., understand the structure and nature of reproduction of this quite easy, faster and ubiquitous immaterial object - the knowledge in the digital environment. Therefore, that is the point in which tools and technologies become essential. It is impossible to be easy, faster and ubiquitous without the support of digital technologies and internet. The effect of this reality may be observed in any sector: health, agribusiness, education, software etc. However, how teachers and students in developing countries can face this complex situation working in public schools that more and more resemble prisons: closed rooms, pupils in line, the familiar sound of a ringing bell, violence? The teacher's mission still looks like the priest who preaches canonical themes disconnected of the students' lives, wrote freshly a Brazilian sociologist (Sodré, 2012). Furthermore, developing countries have a long tradition of importing educational models without the reflection that education is in essence a political issue. A complete understanding of the society is required to propose a new model of educational, simply because education reshapes the cultural and sociological base of an entire society. As McLuhan (1964) said: "We shape our tools, and afterwards our tolls shape us". In addition, the importing practices often demonstrated a blind cultural superiority that we cannot agree anymore. A clearer view of the education, its possibilities and foundations, involves a wellfunded observation on the basis and principles of the model education. However, I guess we should look objectively at both positive and negative consequences effects of any education model, not with the priori assumption that any model is always positive or if it is good for others will be for us.

First things first - if we agree that modern education may be seem as a complex framework connected to the history, society and its economic structure in a given cultural stage, then we must underline that education is essentially a political construction. Consequently, we can't go on working with educational models ignoring what they have been done in our societies - discarding millions of kids and persons, treating them as collateral failures or statistic, despite we know that an uncountable amount of them is extremely intelligent. Systems that produce these circumstances would never provide effective solutions to developing countries; because one of the pillars of countries in development is the extreme inequality and I, sure we want to move away from these circumstances. However, in order to innovate with learning at home it is advantageous a widespread vision of abroad, something like act locally but thinking globally (Morin, 1999). Most important, if we want to use the profitable side of this capitalism phase, we have to consider that, different from mercantile and industrial times, in cognitive capitalism the value is on immaterial assets (Cvijanovic, Fumagalli and Vercellone, 2010). In most countries of Latin America, this picture of educational gears is also worsened because institutional systems of education frequently neglected that the majority of population is formed on oral cultures; on the contrary, what we have seen is that oral cultures are general assumed as an inferior realm, associated with non-literates people that should take the culture of writing. We have to change what at first sight seem disadvantageous into advantageous and reject educational models that do not recognize the real value of the intellectual traditions of non-literate cultures, do not respect the traditional livelihoods, its knowledge system, and the diversity that characterizes humankind. The cleavage between elitist ideas of higher culture of writing against a supposed inferior oral culture was one of the greatest obstacles towards an authentic democratic society in Latin American. In this scenario, education was only a little part of a foreign realm structure imposed for most of the population. The educational history of this social struggle in Latin 
America denotes why only in the 20th Century the universal suffrage was finally reached: Mexico (1917), Colombia (1936), Chile (1971), Brazil (1988). In this sense, Argentina, Cuba and Uruguay were exceptions, building effective policy of public education with good results in the 20th century. In most of its existence, education in Latin America was a privilege, a strategy to obstacle the full participation of majority people, restricting the access and the welfare to a minority.

Is this situation completely overcome? The answer is not! In addition, that brings another difficulty; we are still fighting with the fact that oral culture is not fully integrated to writing culture. However, at the same time, we are dealing with the challenges of a digital economy. However, internet culture may favors these transformations, especially if we learn to integrate education and the culture shaped on political agenda as open source architecture, free software movement and knowledge sharing. The idea of a multitude in the heart of cognitive capitalism can be a gateway to transform education in developing countries (Hardt and Negri, 2004). A sustainability model for developing countries certainly will involve a concept of nation where the differences can be a matter of advantageous. In addition, none of us is enough sufficient to despise the culture and help of others. For better and worse, we are on the same nave - the earth planet, sharing the lucky or unlucky of the universal destination of humankind. I also would like to mention that education in the $21^{\text {st }}$ century should be more concerned in provide a framework to students understand how our present world works than teaching contents that easy become out of date. From Greece to the late $19^{\text {th }}$ Century, the chief body of western education was influenced by Aristotle's Rhetoric (350 BCE) - Ethos, Pathos and Logos. In the medieval time, the elitist model of trivium (grammar, logic, rhetoric) was a step toward the quadrivium (arithmetic, geometry, music, astronomy), which prepared by comprehensive studies in philosophy and theology (Cope, 1970). It is not difficult to see the remained conceptions of these models even in today's university. Most of contemporary policymaking rhetoric of current education point out that education should be based in the paradigms of knowledge society, which means democratic society, multicultural society, globalized society and sustainable society. The complex relationship between the economy, society and the environment and scientific knowledge requires a cross and multi-disciplinary approach. However, in learning only this, the students are surfing on the waves of events. In order to understand the machine inside it is necessary to go deeper. We are living in a time where education is viewed as a market-driven economic force. However, more than a utilitarian model of livelihood, education should embrace other functions, especially if developing countries want to accomplish better life conditions for the majority of society.

\section{Conclusion}

Notwithstanding the technological literacy related to internet, search tools, mobile apps, tablets, Content Management Systems (CMT), games and the so called learn to learn; the fundamental skills should be related to the requirements of the world's game. Today's education should provide frameworks in which the students learn the intrinsic movement of energy that characterizes our present lives (Bataille, 1949). It has already been said that Capitalism is a machine of appropriation and control of desire, which means repression, submission, and reproduction. The essential paradox is that the system simultaneously encourages and strengths the natural movement of desire; and also attempts to control and limit the flow of energy. The external tools to accomplish are laws, bureaucracy, property, work division and scarcity; the internal are guilt and internalization of debt, among others (Deleuze and Guattari, 1972). Finally yet importantly, the magic of this time is that with internet, technological apps and without the restriction of space and time, education can finally offers the opportunity to access knowledge and the essence of human being to a great number of students. And to know more about our long journey through the earth - which began in Africa, and made us a body and soul filled with of desire, passion, intellectual thoughts, symbolic and non-symbolic, figurative an non-figurative energies. The current model we know attempts to control and limit, but there is a way to open the door and make a different journey - the key is education. This education model may preserves nature and traditional cultures, supporting innovative approaches to learning and understanding what's going on in home and abroad; and finally stopping to feed the modus operandi of this inequality-generating machine.

\section{References}

Aronowitz, S. (2000). The knowledge factory: dismantling the corporate university and creating true higher learning. Boston: Beacon Press. 
Aspalter, C. (2003). The Welfare State in Emerging-Market Economies: With Case Studies on Latin America, Eastern-Central Europe and Asia. Taiwan : Casa Verde Publishing.

Bataille, G. (1949). La part maudite, Paris : Minuit.

Bohme, G. \& Stehr, N. (1986). The knowledge society: The growing impact of scientific knowledge on social relations. Boston: D. Reidel Publishing Company.

Brunner, J. (2004). Higher education in Latin America and the Caribbean. Retrieved from http://mt.educarchile.cl on 2011, February 11.

Cope, E. (1970). An Introduction to Aristotle's Rhetoric, with Analysis Notes and Appendices. New York: G. Olms.

Corsani, A., Dieuaide, P., Lazzarato, M., Maurizio, M., Monnier, J. M., Moulier-Boutang, Y., Paulré, B. \& Vercellone, C. (2001). Le capitalism cognitive comme sortie de la crise du capitalism industriel: un programme de recherché. Paris : Actes du Forum de la Régulation.

Deuleze, G. \& Guattari, F. (1972). L'Anti-CEdip: Capitalisme et Schizophrénie. Paris: Minuit.

Freire, P. \& Macedo, D. (1987). Literacy: Reading the Word and the World. Massachusetts: Bergin and Garvey.

Freire, P. (1978). Pedagogy in Process: The Letters to Guinea-Bissau. New York: Seabury Press.

Freire, P. (1973). New York: Continuum.

Fumagalli, A. \& Lucarelli, S. (2010). Cognitive capitalism as a financial economy of production. In: Cvijanovic, V.; Fumagalli, A.; Vercellone, C. (Eds) Cognitive Capitalism and its Reflections in South-Eastern Europe. Frankfurt: Peter Lang, 9-40.

Fumagalli, A. \& Vercellone, C. (2007). Le capitalisme cognitive. Apports et perspectives. European Journal of Economic and Social Systems, 20 (1).

Hardt, M. \& Negri, A. (2004). Multitude: War and Democracy in the Age of Empire. New York: Penguin.

Kwache, P. (2007). The Imperatives of Information and Communication Technology for Teachers in Nigeria Higher Education. Merlot Journal of Online Learning and Teaching, 3(4), 395-399.

Lévi, S. (1964). C. Mythologiques I: Le cru et le Cuit. Paris: Plon.

Lopez-Segrera, F. (2007). Educación superior internacional comparada: escenarios, temas y problemas. Retrieved from http://www.brunner. cl/ on 2011, March 20.

Magretta, J. (1997). Growth Through Global Sustainability: An Interview with Monsanto's CEO, Robert Shapiro. Harvard Business Review (January/February).

McLuhan, M. (1964). Understanding Media. New York: McGraw Hill.

Meadows, H. D., Meadows, D. L., Randebs, J. \& Behbens, W. W. (1972). The Limits to Growth: A Report for the Club of Rome's Project on the Predicament of Mankind. New York: New American Library.

Meadows, H. D., Meadows, D. L., Randebs, J. \& Behbens, W. W. (1992). Beyond the Limits: Confronting Global Collapse and Envisioning a Sustainable Future. Post Mills, Chelsea Green.

Morin, E. (1999). Les sept saviors nécessaires à l'éducation du futur. Paris, United Nations Educational, Scientific and Cultural Organisation.

Moulier-Boutang, Y. (2007). Le capitalism cognitive : Comprendre la nouvelle grande transformation et ses enjeux. Paris: Ed. Amsterdam.

Pasquinelli, M. (2010). The Ideology of Free Culture and the Grammar of Sabotage. Policy Futures in Education, 8(6), 671-682.

Rullani, E. (2004). Economia della conoscenza: Creatività e valore nel capitalismo delle reti. Milano: Carocci.

Salzer, F. (1982). Structural hearing. Tonal coherence in music. New York: Dover publication.

Sobrinho, B. (1994). Em Defesa do Interesse Nacional: Desinformação e Alienação do Patrimônio Público. São Paulo: Paz e Terra.

Sodré, M. (2012). Reiventando a educação: diversidade, descolonização e redes. Petrópolis: Vozes.

The New York Times. (2012). Understanding the European Crisis Now. Retrieved from http://www.nytimes.com on June 25.

The World Bank. (2012). Global Economic Prospects - June 2012. Retrieved from http://www.worldbank.org on 2012 , June 25.

United Nations. Earth Summit +5. (1997). Changing Our Patterns of Production and Consumption to Save the Global Environment. Published by the United Nations Department of Public Information, DPI/1907/SD, June.

United Nations. Earth Summit +5. (1997). Committee on Economic, Social and Cultural Rights. International. Covenant on Economic, social and Cultural Rights. Retrieved from http://www2.ohchr.org/english/bodies/cescr/ on 2012, June 25. 